Available online:

IMLA http://journal.imla.or.id/index.php/arabi

Arabi : Journal of Arabic Studies, 1 (2), 2016, 24-33

\title{
PENINGKATAN PEMBELAJARAN BAHASA ARAB MELALUI INDEKS KATA DAN FRASA DI MADRASAH IBTIDAIYAH NON PESANTREN
}

\author{
R. Umi Baroroh, M. Jakfar Shodik, Tony Fransiska \\ Universitas Islam Negeri Sunan Kalijaga Yogyakarta \\ E-mail: barorohty@yahoo.co.id
}

\begin{abstract}
The factor of failure in Arabic language learning in Indonesia is the lack of activities in language learning. One of language learning activities is identifying meaning or word meaning and phrase in dictionary. However, word and phrase index developed based on teaching materials at madrasah non-pesantren was not developed yet. Therefore, Research and Development is needed to apply. After having collected the word and phrase index that were collected from teaching materials of Arabic language at MI non-pesantren in Indonesia, then it was tested at MIN Malang. The result showed that: there was a development in Arabic language learning through word and phrase index; that was students' competence to identify meaning and collaboration in understanding text and context in a sentence. After having applied the experiment, students' average score increased from 52 with 19 failed students to 81,26 with 5 failed students.
\end{abstract}

Keywords: learning development, word and phrase index, madrasah non-pesantren

\begin{abstract}
Abstrak
Faktor tidak berhasilnya pembelajaran bahasa arab di Indonesia adalah kurangnya aktivitas belajar bahasa. Salah satu aktivitas belajar bahasa adalah mencari makna atau arti kata dan frasa di dalam kamus. Sementara itu indeks kata dan frasa yang disusun berdasarkan bahan ajar di madrasah non pesantren sampai saat inipun juga belum ada. Oleh karena itu perlu diadakan Research and Development. Setelah indeks kata dan frasa terkumpul dari bahan ajar bahasa Arab MI non pesantren di Indonesia terkumpul, maka dilakukan ujicoba di MIN Malang. Hasilnya, peningkatan yang terjadi dalam pembelajaran bahasa Arab melalui indeks kata dan frasa berupa peningkatan kompetisi mencari makna dan peningkatan kolaborasi dalam mengucapkan kata dan saling mendengarkan kata, frasa dan kalimat dan kolaborasi dalam memahami teks dan konteks kalimat. Terjadi peningkatan dari rata-rata 52 dengan 19 peserta tidak mencapai ketuntasan dan setelah dilakukan ujicoba rata-rata kelas bahasa Arab naik menjadi 81,26 dengan 5 peserta didik yang tidak mencapai ketuntasan.
\end{abstract}

Kata Kunci: peningkatan pembelajaran, indeks kata dan frasa, madrasah non pesantren 


\section{Pendahuluan}

Para tatabahasawan tradisional menjelaskan bahwa kata adalah deretan huruf yang diapit oleh dua buah spasi dan mempunyai satu arti. Banyak penelitian telah menunjukkan bahwa salah satu aspek paling penting bagi pembelajaran bahasa asing adalah penguasaan kata, terlebih dalam buku pelajaran bahasa Sekolah Dasar, maka ada sejumlah pakar yang menaruh perhatian serta mengadakan telaah mengenai hal ini. Anderson memaparkan perkembangan kuantitas kosa kata pada seri bacaan anak-anak Sekolah Dasar kelas pre-primer sejumlah 50 kosakata, kelas primer sejumlah 142 kosa kata, kelas I sejumlah 295 kosakata, kelas II sejumlah 760 kosa kata, kelas III sejumlah 1510 kosakata, kelas IV sejumlah 3020 kosakata, kelas V sejumlah 6040 kosakata dan kelas VI 12080 kosakata.(Tarigan, 1991:6)

Telaah Anderson di atas terjadi dalam bahasa Inggris dan penelitian pada hal yang sama yang diilhami oleh penelitian Anderson pada tahun 2011 menunjukkan bahwa kata di dalam bahan ajar bahasa Arab Madrash Ibtidaiyah di Indonesia yang didasarkan pada buku ajar yang digunakan adalah kelas III MIN Yogyakarta 1 ada 107 kata dengan jenis katanya ada 2 (dua) yaitu kata benda (ism) dan harf. Kata benda ada 100 kata dan harf ada 7. Untuk bahan ajar bahasa Arab kelas IV terdiri atas tiga macam kata yaitu kata kerja (fii), kata benda (ism) dan kata sambung-kata penghubung- idiom (harf) . Kata kerja ada 102 kata, kata benda ada 557 dan kata harf (kata penghubung-kata sambung dan atau idiom) ada 29 kata. Jadi jumlah seluruh kata dalam bahan ajar bahasa Arab kelas IV ada 688 kata. Untuk bahan ajar bahasa Arab kelas V terdiri atas kata benda sebanyak 366, kata kerja sebanyak 86 dan harf sebanyak 21 dengan rincian 10 harf untuk ism, 4 khusus harf untuk kata kerja dan 7 harf untuk ism dan fiil. Sedang buku bahasa Arab kelas VI terdiri atas 346 kata benda, 127 kata kerja dan 24 harf.(Baroroh, 2011:155) Penelitian Baroroh ini baru menyentuh aspek kata dan tidak menyentuk aspek frase (murakkab). Mustafa Galayain menyebut bahwa murakkab adalah:

$$
\text { قَول مؤلّف من كلمتين أو أكثر لفائدة، سواء كانت الفائدة تامة أم ناقصة (Galayain, 1987:12) }
$$

"sebuah perkataan/ucapan yang terdiri dari dua kata atau lebih untuk suatu faedah pemahaman, baik itu sempurna maupun yang tidak sempur".

Ucapan yang telah memiliki faedah pemahaman yang sempurna disebut kalimat dan yang tidak memberikan pemahaman disebut frase. (Alwi, 2010: 162) Persoalan terpenting dalam pembelajaran bahasa Arab untuk non Arab adalah pemilihan kata dan gradasi penyampaiannya. Hal ini diungkap Dr. Abdullah bin Hamid al Hamid sebagai berikut:

$$
\begin{aligned}
& \text { "وأهَمّ الأمور في تعُليم اللعة الثانية إختيار الكلمات، وإمكان التدرج في تقديمها، و خاصة في كتاب تعليم اللغة الثانية، ... و لا توجد }
\end{aligned}
$$

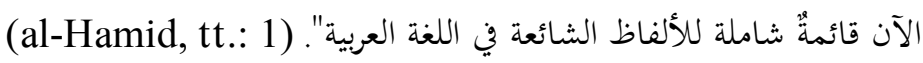

Sementara itu, sampai saat ini belum ditemukan indeks yang lengkap kata-kata yang tersebar dalam bahan ajar bahasa Arab di Indonesia. Padahal bahasa Arab di Indonesia sebagaimana Nazri Syakur telah menelaahnya, masuk di Indonesia bersamaan dengan masuknya agama Islam di Nusantara. (Syakur, 2008: 91), (Effendy, 2009: 27-25). Ini menunjukkan usia pembelajaran bahasa Arab di Indonesia sudah lebih dari sepuluh abad. Meskipun demikian pembelajaran bahasa Arab khususnya di madrasah belum menunjukkan hasil yang optimal bahkan jauh dari yang diharapkan (Baroroh, 2010: 107; Albantani, 2015: 190). Oleh karena itu upaya peningkatan pembelajaran bahasa Arab di madrasah non pesantren merupakan suatu kebutuhan dan kajian terhadapnya merupakan tuntutan bagi pengembangan bahasa Arab di Indonesai. Sehingga rumusan masalah kajian ini adalah Bagaimana peningkatan pembelajaran bahasa Arab di madrasah melalui indeks kata dan frase bahasa Arab dalam bahan ajar bahasa Arab di madrasah non pesantren?

Kajian ini merupakan kajian peningkatan pembelajaran bahasa Arab di madrasah melalui indeks kata dan frase bahasa Arab dalam bahan ajar bahasa Arab di madrasah non pesantren di Indonesia. Langkah-langkah kajiannya dengan menggunakan research and development dengan langkah-langkah sebagaimana diuraikan di dalam gambar berikut ini: 


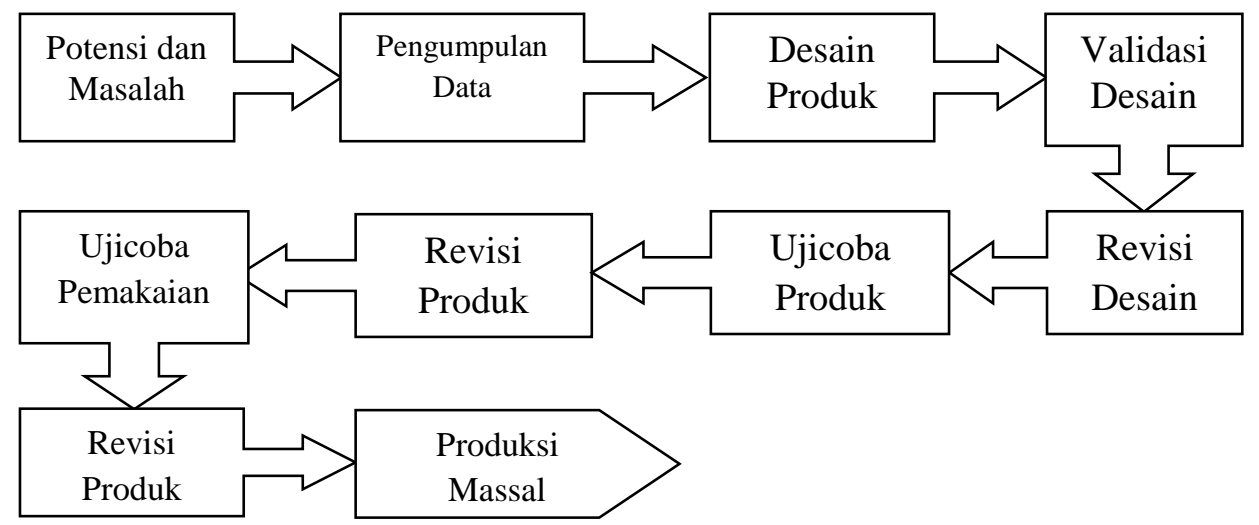

Gambar 1. Langkah-langkah penggunaan Metode Research and Development (R\&D).

Langkah-langkah $\mathrm{R} \& \mathrm{D}$ di atas sampai selesainya laporan ini ditulis tidak semuanya diterapkan di dalam peneitian ini. Langkah yang ditempuh setelah potensi masalah dan pengumpulan data dan dilanjutkan desain produk adalah uji coba. Uji coba dilakukan di Madrasah Ibtidaiyah Negeri Malang, Lokasi pemilihan tempat dipilih secara random. Dikarenakan uji cobanya merupakan ujicoba sederhana, maka dari setiap bahan ajar yang ada diujicoakan satu tema. Untuk Madrasah Ibtidaiyah Uji coba dilakukan terhadap kelas V dengan tema fi al hadiqah.

\section{Indeks Kata dan Frase dalan Bahan Ajar Madrasah Aliyah Non Pesantren}

Bahan ajar bahasa Arab Madrasah Ibtidaiyah non pesantren di Indonesia tahun ajaran 20152016 yang dijadikan bahan dalam penyusunan indeks kata dan frase adalah bahan ajar bahasa Arab MI yang digunakan di berbagai Madrasah Ibtidaiyah non pesantren yang tersebar di berbagai wilayah di Indonesia (Jawa Tengah, Jawa Timur dan Jawa Barat, Medan, Riau, Bengkulu, dan NTB), yang didapat dari wawancara dan observasi. Adapun rincian bahan ajar bahasa Arab MI tersebut adalah sebagai berikut:

1. Bahan Ajar Bahasa Arab Kelas 1 MI Non Pesantren di Indonesia

\begin{tabular}{|l|l|l|l|l|l|}
\hline No & \multicolumn{1}{|c|}{$\begin{array}{c}\text { Penulis/ } \\
\text { Kontributor }\end{array}$} & \multicolumn{1}{|c|}{ Judul } & \multicolumn{1}{|c|}{$\begin{array}{l}\text { Kota } \\
\text { Terbit }\end{array}$} & \multicolumn{1}{|c|}{ Penerbit } \\
\hline 1 & $\begin{array}{l}\text { Abdi Pemi } \\
\text { Karyanto, dkk }\end{array}$ & $\begin{array}{l}\text { Buku Siswa Pendekatan Saintifik } \\
\text { Kurikulum 2013 Kelas 1 Madrasah } \\
\text { Ibtidaiyah }\end{array}$ & Jakarta & Kemenag RI & 2014 \\
\hline 2 & $\begin{array}{l}\text { H.D Hidayat, } \\
\text { dkk }\end{array}$ & $\begin{array}{l}\text { Pelajaran Bahasa Arab Kurikulum 2013 } \\
\text { Kelas 1 }\end{array}$ & Semarang & Toha Putra & 2014 \\
\hline 3 & Tim Penulis & $\begin{array}{l}\text { LKS - Bahasa Arab Madrasah Ibtidaiyah } \\
\text { Kelas 1, Semester 1 }\end{array}$ & Surakarta & CV. Ar Rahman & t.th \\
\hline 4 & Tim Penulis & $\begin{array}{l}\text { Media Penilaian Autentik Bahasa Arab } \\
\text { untuk kelas I MI }\end{array}$ & Solo & Tiga Serangkai & 2015 \\
\hline
\end{tabular}

Gambar 2. Bahan Ajar Bahasa Arab Kelas I MI non Pesantren di Indonesia

Dari keempat buku tersebut tersusun indeks kata sejumlah untuk kata benda 97 kata, kata kerja 20 kata dan harf ada 5 kata. Dan frase ada 47. Frase yang muncul di buku ajar MI adalah frase wasfi dan frase idhafy.

2. Bahan Ajar MI Kelas 2 MI Non Pesantren di Indonesia

\begin{tabular}{|l|l|l|l|l|l|}
\hline No & \multicolumn{1}{|c|}{$\begin{array}{c}\text { Penulis/ } \\
\text { Kontributor }\end{array}$} & \multicolumn{1}{|c|}{ Judul } & \multicolumn{1}{|c|}{$\begin{array}{l}\text { Kota } \\
\text { Terbit }\end{array}$} & \multicolumn{1}{|c|}{ Penerbit } & \\
\hline 1 & Tim Penulis & $\begin{array}{l}\text { Buku Siswa Bahasa Arab Pendekatan } \\
\text { Saintifik Kurikulum 2013 Madrasah } \\
\text { Ibtidaiyah II }\end{array}$ & Jakarta & Kemenag RI & 2015 \\
\hline 2 & $\begin{array}{l}\text { H.D. Hidayat, } \\
\text { dkk }\end{array}$ & $\begin{array}{l}\text { Pelajaran Bahasa Arab Kurikulum 2013 } \\
\text { Madrasah Itidaiyah Kelas 2 }\end{array}$ & Semarang & Toha Putra & 2015 \\
\hline 3 & Tim Penulis & $\begin{array}{l}\text { Media Penilaian Autentik Bahasa Arab } \\
\text { untuk Kelas II MI }\end{array}$ & Solo & Tiga Serangkai & 2015 \\
\hline
\end{tabular}

Vol. 1 No. 2 |26-33

Copyright @ 2016 | ARABI | p-ISSN 2548-6616 | e-ISSN 2548-6624 
Arabi : Journal of Arabic Studies

\begin{tabular}{|l|l|l|l|l|l|}
\hline 4 & Tim Penulis & $\begin{array}{l}\text { LKS - Dimensi Bahasa Arab Semester I } \\
\text { Kelas II }\end{array}$ & Surakarta & CV. Ar Rahman & t.th \\
\hline 5 & Tim penulis & $\begin{array}{l}\text { Kurikulum 2013 THAWAF Bahasa Arab } \\
\text { 2/1-MI }\end{array}$ & t.tp & Citra Pustaka & t.th \\
\hline
\end{tabular}

Gambar 3. Bahan Ajar Bahasa Arab Kelas II MI non Pesantren di Indonesia

Dari kelima buku di atas tersusun indeks kata dan frase bahasa Arab MI non pesantren kelas 2 d Indonesia sebagai berikut. Kata benda seabnyak 197 kata, kata kerja (fi'il) sebanyak 21, kata partikel $(h u n \bar{u} f)$ sebanyak 16 dan frase sebanyak 37 frase. Jenis frase yang muncul ada tiga yaitu frase washfi, frase idhāfi dan frase badati.

3. Bahan Ajar Bahasa Arab Kelas 3 MI di Indonesia

\begin{tabular}{|l|l|l|l|l|l|}
\hline No & \multicolumn{1}{|c|}{$\begin{array}{c}\text { Penulis/ } \\
\text { Kontributor }\end{array}$} & \multicolumn{1}{|c|}{ Judul } & \multicolumn{1}{|c|}{$\begin{array}{l}\text { Kota } \\
\text { Terbit }\end{array}$} & \multicolumn{1}{|c|}{ Penerbit } & Kemenag RI \\
\hline 1 & Tim Penulis & $\begin{array}{l}\text { Buku Siswa Bahasa Arab Pendekatan } \\
\text { Saintifik Kurikulum 2013 Madrasah } \\
\text { Ibtidaiyah III }\end{array}$ & Jakarta & 2015 \\
\hline 2 & $\begin{array}{l}\text { H.D. Hidayat, } \\
\text { dkk }\end{array}$ & $\begin{array}{l}\text { Pelajaran Bahasa Arab Kurikulum 2013 } \\
\text { Madrasah Ibtidaiyah Kelas 3 }\end{array}$ & Semarang & Toha Putra & 2015 \\
\hline 3 & Tim Penulis & $\begin{array}{l}\text { LKS - Dimensi Bahasa Arab Semester I } \\
\text { Kelas III }\end{array}$ & Surakarta & CV. Ar Rahman & t.th \\
\hline
\end{tabular}

Gambar 4. Bahan Ajar Bahasa Arab Kelas III MI non Pesantren di Indonesia

Berdasarkan ketiga buku tersebut disusun indek kata yang terdiri atas 218 kata benda, 48 kata kerja, 28 hurf dan 111 frase. Jenis frase yang terdapat di dalam bahan Arab MI kelas 3 adalah murakkab washfi, murakkab idhafi dan murakkab badah

4. Bahan Ajar Bahasa Arab Kelas 4 MI di Indonesia

\begin{tabular}{|c|c|c|c|c|c|}
\hline No & $\begin{array}{c}\text { Penulis/ } \\
\text { Kontributor }\end{array}$ & Judul & $\begin{array}{l}\text { Kota } \\
\text { Terbit }\end{array}$ & Penerbit & Tahun \\
\hline 1 & Tim Penulis & $\begin{array}{l}\text { Buku Siswa Bahasa Arab Pendekatan } \\
\text { Saintifik Kurikulum } 2013 \text { Madrasah } \\
\text { Ibtidaiyah IV }\end{array}$ & Jakarta & Kemenag RI & 2014 \\
\hline 2 & H.D. Hidayat, dkk & $\begin{array}{l}\text { Pelajaran Bahasa Arab Kurikulum } 2013 \\
\text { Madrasah Ibtidaiyah Kelas } 4\end{array}$ & Semarang & Toha Putra & 2014 \\
\hline 3 & $\begin{array}{l}\text { A.Syaekhuddin, } \\
\text { Halid al Kaf, Jalal } \\
\text { Suyuti }\end{array}$ & $\begin{array}{l}\text { Belajar Bahasa Arab untuk Madrasah } \\
\text { Ibtidaiyah Kelas IV }\end{array}$ & Jakarta & Erlangga & 2009 \\
\hline 4 & Agus Wahyudi & $\begin{array}{l}\text { Aku Cinta Bahasa Arab untuk Kelas IV } \\
\text { Madrasah Ibtidaiyah }\end{array}$ & Solo & Tiga Serangkai & 2010 \\
\hline 5 & Tim Penulis, & $\begin{array}{l}\text { LKS - Dimensi Bahasa Arab Madrasah } \\
\text { Ibtidaiyah Semester } 1 \text { Kelas IV }\end{array}$ & Surakarta & CV. Ar Rahman & t.th \\
\hline 6 & Tim Penulis & $\begin{array}{l}\text { LKS - Dimensi Bahasa Arab Madrasah } \\
\text { Ibtidaiyah Semester } 2 \text { Kelas VI }\end{array}$ & Surakarta & CV. Ar Rahman & t.th \\
\hline 7 & $\begin{array}{l}\text { Uswatul Hasanah, } \\
\text { S.Ag. dkk }\end{array}$ & $\begin{array}{l}\text { LKS - Sabila Senang Belajar Agama } \\
\text { Islam Mata Pelajaran al Qur'an Hadits, } \\
\text { Aqidah Akhlak, Fiqih, Sej. Kebb. Islam } \\
\text { dan Bahasa Arab untuk Madrasah } \\
\text { Ibtidaiyah/SDI Kelas } 4 \text { semester } 1\end{array}$ & Malang & Pustaka Grafika & t.th \\
\hline 8 & $\begin{array}{l}\text { Uswatul Hasanah, } \\
\text { S.Ag. dkk }\end{array}$ & $\begin{array}{l}\text { LKS - Sabila Senang Belajar Agama } \\
\text { Islam Mata Pelajaran al Qur'an Hadits, } \\
\text { Aqidah Akhlak, Fiqih, Sej. Kebb. Islam } \\
\text { dan Bahasa Arab untuk Madrasah } \\
\text { Ibtidaiyah/SDI Kelas } 4 \text { semester } 2 \\
\end{array}$ & Malang & Pustaka Grafika & t.th \\
\hline 9 & Tim Penulis & $\begin{array}{l}\text { LKS - Dimensi Bahasa Arab Madrasah } \\
\text { Ibtidaiyah Semester } 1 \text { Kelas IV }\end{array}$ & Surakarta & CV. Ar Rahman & t.th \\
\hline
\end{tabular}

Gambar 5. Bahan Ajar Bahasa Arab Kelas IV MI non Pesantren di Indonesia

Dari buku-buku di atas terkumpul kata kerja ( i $^{\prime} i$ ) sebanyak 81 kata, kata benda (isim) sebanyak 322 kata, harfada 31 kata dan frase sebanyak 84 frase (murakkab). 


\section{Arabi : Journal of Arabic Studies}

5. Bahan Ajar Bahasa Arab Kelas V MI di Indonesia

\begin{tabular}{|l|l|l|l|l|l|}
\hline No & \multicolumn{1}{|c|}{$\begin{array}{c}\text { Penulis/ } \\
\text { Kontributor }\end{array}$} & \multicolumn{1}{|c|}{ Judul } & \multicolumn{1}{|c|}{$\begin{array}{l}\text { Kota } \\
\text { Terbit }\end{array}$} & \multicolumn{1}{|c|}{ Penerbit } & \multicolumn{1}{|c|}{ Tahun } \\
\hline 1 & Tim Penulis & $\begin{array}{l}\text { Buku Siswa Pendekatan Saintifik } \\
\text { Kurikulum 2013 }\end{array}$ & Jakarta & Kemenag RI & 2015 \\
\hline 2 & $\begin{array}{l}\text { H.D. Hidayat, } \\
\text { dkk }\end{array}$ & $\begin{array}{l}\text { Pelajaran Bahasa Arab Madrasah } \\
\text { Ibtidaiyah Kurikulum 2008 kelas 5 }\end{array}$ & Semarang & Toha Putra & 2002 \\
\hline 3 & Agus Wahyudi & $\begin{array}{l}\text { Lancar Berbahasa Arab 3 untuk Kelas V } \\
\text { Madrasah Ibtidaiyah }\end{array}$ & Solo & Tiga Serangkai & 2009 \\
\hline 5 & Tim Penulis & $\begin{array}{l}\text { Media Penilaian Autentik Bahasa Arab } \\
\text { untuk Kelas VMI }\end{array}$ & Solo & Tiga Serangkai & 2015 \\
\hline 6 & Tim Penulis & $\begin{array}{l}\text { LKS - Dimensi Bahasa Arab Madrasah } \\
\text { Ibtidaiyah Semester 1 Kelas V Surakarta }\end{array}$ & CV. Ar Rahman & t.th \\
\hline $\begin{array}{l}\text { Kurikulum 2013 THAWAF Bahasa Arab } \\
\text { 5/1-MI }\end{array}$ & t.tp & Citra Pustaka & t.th \\
\hline
\end{tabular}

Gambar 6. Bahan Ajar Bahasa Arab Kelas V MI non Pesantren di Indonesia

Dari keenam buku di atas terkumpul kata kerja ( $f i^{\prime}$ il) sebanyak 81 kata, kata benda (isim) sebanyak 515 dan kata tugas/partikel (huñ f) sebanyak 36 buah. Frase yang muncul sebanyak 74 frase terdiri dari frase washfi, frase idhafi, frase badat dan frase tauki dì.

6. Buku Ajar Bahasa Arab Kelas VI MI di Indonesia

\begin{tabular}{|c|c|c|c|c|c|}
\hline No & $\begin{array}{l}\text { Penulis/ } \\
\text { Kontributor }\end{array}$ & Judul & $\begin{array}{l}\text { Kota } \\
\text { Terbit }\end{array}$ & Penerbit & Tahun \\
\hline 1 & Tim Penulis & $\begin{array}{l}\text { Buku Siswa Bahasa Arab Pendekatan } \\
\text { Saintifik Kurikulum } 2013 \text { kelas } 6\end{array}$ & Jakarta & Kemenag RI & 2015 \\
\hline 2 & $\begin{array}{l}\text { H.D. Hidayat, } \\
\text { dkk }\end{array}$ & $\begin{array}{l}\text { Pelajaran Bahasa Arab Madrasah } \\
\text { Ibtidaiyah Kurikulum } 2008 \text { kelas } 6\end{array}$ & Semarang & Toha Putra & 2002 \\
\hline 3 & $\begin{array}{l}\text { Uswatul } \\
\text { Hasanah, S.Ag. } \\
\text { dkk }\end{array}$ & $\begin{array}{l}\text { LKS - Sabila Senang Belajar Agama Islam } \\
\text { Mata Pelajaran al Qur'an Hadits, Aqidah } \\
\text { Akhlak, Fiqih, Sej. Kebb. Islam dan } \\
\text { Bahasa Arab untuk Madrasah } \\
\text { Ibtidaiyah/SDI Kelas } 6 \text { semester } 1\end{array}$ & Malang & Pustaka Grafika & t.th \\
\hline 4 & $\begin{array}{l}\text { Uswatul } \\
\text { Hasanah, S.Ag. } \\
\text { dkk }\end{array}$ & $\begin{array}{l}\text { LKS - Sabila Senang Belajar Agama Islam } \\
\text { Mata Pelajaran al Qur'an Hadits, Aqidah } \\
\text { Akhlak, Fiqih, Sej. Kebb. Islam dan } \\
\text { Bahasa Arab untuk Madrasah } \\
\text { Ibtidaiyah/SDI Kelas } 6 \text { semester } 2\end{array}$ & Malang & Pustaka Grafika & t.th \\
\hline 5 & Tim Penulis & $\begin{array}{l}\text { Dimensi Bahasa Arab Madrasah } \\
\text { Ibtidaiyah Semester } 1 \text { Kelas VI }\end{array}$ & Surakarta & CV. Ar Rahman & t.th \\
\hline 6 & Tim Penulis & $\begin{array}{l}\text { AZZA Cerdas \& Berakhlak Materi } \\
\text { Pengayaan Bahasa Arab Kelas VI }\end{array}$ & Semarang & Avar Mandiri & t.th \\
\hline
\end{tabular}

Gambar 7. Bahan Ajar Bahasa Arab Kelas VI MI non Pesantren di Indonesia

Dari keenam buku tersebut terkumpul 207 kata benda, 168 kata kerja dan 41 harf serta 52 frase. Jenis frase yang muncul di kelas VI adalah frase washfi, frase idhāfi dan frase badat. Berdasarkan identifikasi dan klasifikasi kata dan frase dalam bahan Ajar Bahasa Arab Madrasah Ibtidaiyah non Pesantren diketahui bahwa jumlah kata bahasa Arab dari kelas 1 sampai kelas VI Madrasah Ibtidaiyah secara keseluruhan berjumlah 2038 kata. Yakni dengan rincian kata benda (isim) 1462 kata, kata kerja (fi'il) 419 dan kata tugas/partikel (hurüf) ada 157, serta frasenya berjumlah 464 .

\section{Pembelajaran Bahasa Arab Melalui Indeks Kata dan Frase}

Paradigma baru pendidikan Indonesia saat ini adalah student centereted. Sebuah paradigma yang mengedepankan peserta didik sebagai pusat yang beraktifitas. Peran guru telah bergeser dari selalu memberi materi berpindah pada guru sebagai fasilitator dan inisiator dalam kegiatan belajar. Belajar bahasa Arab dengan indeks kata dan frase merupakan salah satu inisiatif untuk membantu terwujudnya paradigma student centered dalam pembelajaran bahasa Arab. 
Uji coba pembelajaran bahasa Arab dengan indeks kata dan frase ini bertujuan untuk mengetahui peningkatan pembelajaran bahasa Arab melalui indeks kata dan frase. Uji coba ini menggunakan rancangan Pasca-tes pada kelompok Ekuivalen. Ada kelompok eksperimen dan ada kelompok kontrol. Pada kelompok eksperimen dikenai treatment $\mathrm{T}-1$ yaitu pembelajaran dengan menggunakan kata dan frase dalam bahan ajar bahasa Arab, dan pada kelompok kontrol dikenai treatment T-2 yaitu pembelajaran dengan metode ceramah. Pemilihan kelompok dilakukan secara random. Model eksperimen ini ditunjukkan pada gambar berikut:
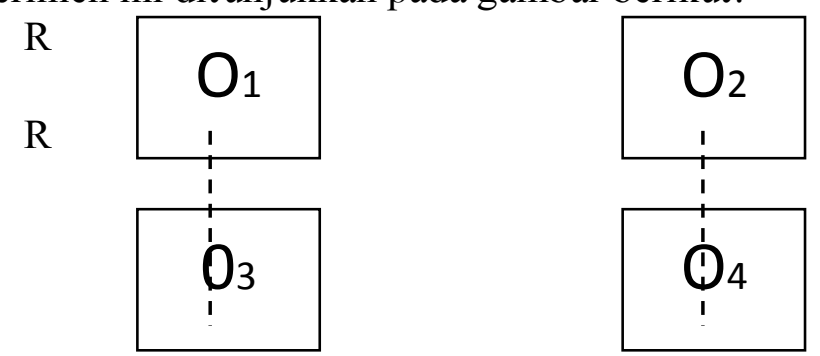

Gambar 8. Desain eksperimen dengan kelompok kontrol (pretest-postest control group desain)

Berdasarkan gambar tersebut diberikan penjelasan sebagai berikut. Sebelum sistem kerja baru yaitu pembelajaran bahasa Arab dengan indeks kata dan frase dicobakan, maka dipilih dipilih kelas yang akan menggunakan sistem kerja tersebut. Karena kelasnya banyak, maka eksperimen dilakukan pada sampel yang dipilih secara random. Kelas V MIN Malang tahun Ajaran 2015-2015 ada 8 kelas. Kelompok pertama yang akan menggunakan indeks kata dan frase dalam bahan ajar disebut sebagai kelompok eksperimen, sedangkan kelompok yang tetap menggunakan metode dan cara pembelajaran lama disebut kelas kontrol. $\mathrm{R}$ berarti pengambilan kelompok eksperimen dan kelompok kontrol dilakukan secara random. Kedua kelompok tersebut selanjutnya diberi pretest untuk mengetahui kemampuan kedua kelompok tersebut. O1 adalah nilai kemampuan awal kelompok eksperimen dan $\mathrm{O} 3$ adalah nilai kemampuan awal kelompok kontrol. $\mathrm{O} 2$ adalah nilai kelompok kesperimen setelah menggunakan indeks kata dan frase dalam bahan Ajar dan O4 adalah nilai kelompok kontrol yang tetap menggukanan pembelajaran sistem lama. Bila nilai O2 secara signifikan lebih tinggi dari O4, maka terjadi peningkatan pembalajaran bahasa Arab melalui indeks kata dan frase dalam bahan ajar. Hanya saja karena keterbatasan waktu yang ada penelitian ini belum sampai pada tahap pengukuran signifikansi efektivitas dari pembelajaran melalui kata dan frase ini.

Secara sistematis, proses pembelajaran bahasa Arab melalui kata dan frase di tingkat Madrasah Ibtidaiyah dilakukan langkah-langkah pembelajaran sebagai berikut:

\section{Kegiatan Pendahuluan}

a) Guru menyiapkan fisik dengan brain game dalam hal ini guru mengajak peserta didik menggambar angka delapan di awang-awang pertama dengan satu tangan kanan, kemudian dengan tangan kiri dan berikutnya bersamaan menggambar angka 8 dengan tangan kiri dan menyiapkan psikhis peserta didik dengan berdoa dan mengabsen nama peserta didik.

b) Guru memotivasi peserta didik dengan menceritakan banyak orang sukses karena menguasai bahasa Arab dan mereka menguasai belajar dengan tidak jemu-jemunya membuka kamus untuk mengerti arti dari setiap kata dan juga frase dari bahasa Arab itu.

c) Guru menyampaikan tujuan pembelajaran, tujuan pembelajaran bahasa Arab dengan tema fi al Hadíqah adalah sebagai berikut :

$\Rightarrow$ Kompetensi Inti: .Memahami pengetahuan faktual dan konseptual dengan cara mengamati dan mencoba berdasarkan rasa ingin tahu tentang dirinya, makhluk ciptaan Tuhan dan kegiatannya, dan benda-benda yang dijumpainya di rumah, di kebun, di sekolah dan tempat bermain. 


\section{Arabi : Journal of Arabic Studies}

$\Rightarrow$ Kompetensi Dasar. 3.2 Memahami bentuk dan makna kata, frase, kalimat sederhana sesuai dengan unsur kebahasaan dan terkait topik في الحديقة baik secara lisan maupun tertulis.

$\Rightarrow$ Indikator Hasil Belajar:

1) Siswa dapat menentukan kata benda yang tepat untuk melengkapi kalimat yang tidak lengkap.

2) Siswa dapat menentukan kata tanya yang tepat untuk melengkapinya

3) Siswa dapat melengkapi kalimat rumpang dengan mufradat yang sesuai.

4) Siswa dapat menentukan isim/isyārah/sifat yang tepat untuk melengkapinya.

5) Siswa dapat melengkapi dengan mufradat yang sesuai.

d) Guru menyampaikan cakupan materi dan langkah-langkah pembelajaran. Pertama, Kelompok eksperimen: Pembelajaran bahasa Arab dengan kata dan frase yakni 1) Guru membagi kelas ke dalam beberapa kelompok; setiap kelompok maksimal 5 anak. 2) Setelah berkelompok, masing-masing kelompok membaca secara bergantian kata dan frase yang telah disediakan dengan suara yang dapat didengar kelompoknya sampai mereka lancar membaca dan mengerti artinya, 3) Setelah itu mereka membaca materi yang ada di buku pegangan, 4) Mengerjakan latihan; 5) Tanya jawab dengan guru.

Kedua, Kelompok kontrol: Pembelajaran bahasa Arab dilakukan oleh guru menggunakan metode sebagaimana biasanya guru menggunakannya yaitu metoe ceramah.

e) Pretest; Guru memberikan soal sebagai pretes kepada anak. Soal disusun dengan kisi-kisi soal yang dibuat guru bahasa Arab sebagai berikut:

$\Rightarrow$ Disajikan kalimat tentang في الحديقة yang belum sempurna, siswa dapat menentukan kata benda yang tepat untuk melengkapinya;

$\Rightarrow$ Disajikan kalimat sempurna tentang في الحديقة. siswa dapat menentukan kata tanya yang tepat untuk melengkapinya.Disajikan kalimat tentang في الحديقة. yang belum sempurna, siswa dapat menentukan kata benda yang tepat untuk melengkapinya;

$\Rightarrow$ Siswa dapat melengkapi kalimat rumpang dengan mufradat yang sesuai;

$\Rightarrow$ Disajikan kalimat tentang في الحديقة yang belum sempurna, siswa dapat menentukan isim/isyarah/sifat yang tepat untuk melengkapinya;

$\Rightarrow$ Disajikan kalimat rumpang tentang kebun Siswa dapat melengkapi dengan mufradat yang sesuai;

$\Rightarrow$ Disajikan dialog tentang في الحديقة yang belum sempurna, siswa dapat melengkapi dengan kata/kalimat yang tepat;

$\Rightarrow$ Disajikan kata acak tentang في الحديقةsiswa dapat menentukan susunan kalimat yang benar;

$\Rightarrow$ Disajikan kalimat tentang في الحديقة dalam bahasa Indonesia, siswa dapat menerjemahkan dalam bahasa Arab dengan tepat;

$\Rightarrow$ Disajikan kalimat tentang في الحديقة siswa dapat menerjemahkan dalam bahasa Indonesia dengan tepat.

\section{Kegiatan Inti}

a) Siswa berkelompok membaca dengan suara bergantian kata dan frase yang telah disediakan. Tema fi al-Hadiqah terdiri atas 62 kata benda, 8 kata kerja 5 kata sambung (harf), 31 frase dan 15 ungkapan. Guru memperhatikan dengan berkeliling dan membenarkan jika terdapat siswa yang membaca tidak benar. Berikut ini gambar yang menunjukkan aktifitas siswa dan guru saat siswa membaca indeks kata dan frase dengan suara nyaring secara bergantian:

b) Siswa membaca dan memahami materi yang ada di buku secara kelompok; setelah secara berkelompok peserta didik membaca kata dan frase desertai dengan arti yang dimaksud dari kata dan frase, peserta didik membaca teks dalam bahan ajar bahasa Arab, secara nyaring dan bergantian sambil memahami kalimat dalam bacaan secara keseluruhan. 
Setiap peserta didik mendapat kesempatan yang sama untuk membacakan teks dan mendengarkan sambil membenarkan bacaan teman yang salah.

c) Peserta didik mengerjakan latihan-latihan secara berkelompok;

d) Peserta didik melakukan dialog sesuai teks dalam buku dalam kelompok masing-masing;

e) Peserta didik dan guru bertanya jawab.

\section{Kegiatan Penutup}

Ada empat kegiatan yang dilakukan guru dalam kegiatan penutup. Keempat kegiatan tersebut adalah:

a. Guru menanyakan apa saja yang telah anak-anak pelajari dan apa yang telah mereka peroleh. Dengan semangat peserta didik menjawab bahwa mereka telah membaca dan mendengarkan teks kosa kata dan frase, membaca teks bahasa Arab tema fi al hadiiqah dan mengerjakan soal;

b. Post-test; Post test diberikan setelah selesai semua pembahasan materi yaitu pada akhir pertemuan kedua tema fi al hadiqah. Kisi-kisi soal post test sama dengan kisi-kisi soal pretest sebagaimana di atas.Hasil rata-rata kelas eksperimen setelah diterapkannya pembelajaran bahasa Arab melalui indeks kata dan frase adalah 81, 26 dan peserta didik yang tidak mencapai nilai ketuntasan berjumlah 5. Sedangkan kelas kontrol nilai rata-rata peserta didik adalah 72,75;

c. Guru menyampaikan materi yang akan datang dan kelas ditutup dengan bersama membaca hamdalah.

\section{Peningkatan Pembelajaran Bahasa Arab Melalui Indeks Kata dan Frase dalam Bahan Ajar Bahasa Arab Madrasah Ibtidaiyah}

\section{Peningkatan Aktifitas Belajar Siswa}

Pembelajaran bahasa Arab melalui indeks kata dan frase sebagaimana yang telah berlangsung di atas mendorong peserta didik melakukan sendiri aktivitas belajar dengan bekerja sama dengan teman sebayanya. Aktivitas belajar di sini meliputi membaca, mendengarkan, mencoba sendiri dan mengikuti perintah. Hal ini sebagaimana Cronbach (1954) dalam buku Educational Psychology mengatakan bahwa learning is shorn by a change in behavior as a result of experience. (Suryabrata, 1990:247) Hal ini menunjukkan bahwa belajar yang sebaik-baik belajar adalah dengan mengalami dan dalam mengalami ini pebelajar akan mempergunakan panca inderanya.

Membaca yaitu peserta didik membaca nyaring kata dan frase dengan arti dan makna yang langsung ia dapat memahaminya dan ketika ia membaca dan sudah mengerti arti kata dan frase tersebut, maka bersamaan dengan itu ia mencerna arti dari kata yang diucapkan. Setelah membaca kata dan frase maka akan dilanjutkan dengan membaca teks yang semua kata dan frasenya sudah dipahami, maka ia akan lebih mudah memahami kalimat dan akan lebih menginternal di dalam dirinya. Hasan Syahatah menyatakan bahwa aktivitas berbahasa ini akan membantu peserta didik memperoleh kompetensi berbahasa berupa pengetahuan, keterampilan dan nilai secara efektif. (Syahatah, tt.:371) Membaca nyaring menjadikan peserta didik berlatih mengucapkan kata, frase dan kalimat dengan benar. Pengucapan yang benar akan meningkatkan kepercayaaan diri peserta didik akan keberhasilan belajarnya. Indera yang digunakan di dalam membaca adalah indera penglihatan.

Mendengarkan adalah belajar dengan menggunakan indra pendengaran yaitu di saat temannya membacakan kata dan frase, peserta didik lainnya mendengarkan dengan melihat teks sehingga ia memahami kata ataupun frase dan ungkapan yang didengarnya dalam konteks kalimat yang utuh. Hal ini menjadikan perhatian peserta didik meningkat. Jika satu kelompok terdiri atas 4 anak, maka setiap anak akan mendapatkan kesempatan mendengar empat kali dan ditambah empat kali bacaan teks secara lengkap. Hal ini berarti peserta didik melakukan kegiatan rehearsal (practice or repetition of the materials)(Kimble, 1974:413) yaitu mengulang materi pelajaran. 


\section{Arabi : Journal of Arabic Studies}

Sebuah kegiatan yang memiliki peran besar dalam mewujudkan long-term memory (ingatan jangka panjang).

Selain peningkatan kegiatan belajar yang dilakukan peserta didik, kegiatan pembelajaran dengan indeks kata dan frase di atas menjelaskan terjadinya kerjasama dan kolaborasi di antara para peserta didik. Dengan bekerja sama dan berkolaborasi peserta didik akan memahami indahnya kebersamaan saling memberi dan bermanfaat untuk terwujudnya kompetensi berbahasa Arab.

Aktifitas Belajar berikutnya yang meningkat adalah adanya kegiatan dialog antar peserta didik setelah pembacaan teks selesai. Syahatah menyebutkan salah satu dari bentuk tempat beraktifitas bahasa adalah nādi al lugah yaitu tempat berkumpulnya para peserta didik untuk saling memberi penguatan berbahasa, berdiskusi dll. sehingga akan berkembang keterampilan menyimak, kebiasaan membaca, latihan percakapan, menyampaikan ide, khitobah dan menulis. (Syahatah, tt.:390) Nādi al lugah merupakan pengembangan dari kolaborasi peserta didik.

\section{Peningkatan Hasil Belajar}

Hasil belajar bahasa adalah berupa terjadinya perubahan pada diri pembelajar dari tidak bisa berbahasa menjadi bisa berbahasa, perubahan dari tidak mengerti makna kata berubah menjadi mengerti dan memahami makna kata, perubahan dari tidak bisa mengucapkan berubah menjadi berkemampuan mengucapkan dengan lancar. Dan sebagaimana yang sudah ditentukan di dalam indikator bahwa perubahan yang diharapkan terwujud pada diri peserta didik ada lima sebagaimana telah disebutkan di atas. Di dalam ilmu pendidikan hasil belajar dapat diketahui dengan baik apabila direncanakan penilaiannya. Hal-hal yang direncanakan dalam penilaian hasil belajar adalah sebagai berikut:

1. Merumuskan tujuan;

2. Menetapkan aspek-aspek yang dinilai;

3. Menetapkan metode;

4. Menyiapkan alat-alat. (Nurkancana, 1986: 18)

Dari hasil pre-test dan post-test terhadap kelompok eksperimen terdapat peningkatan hasil belajar yang signifikan. Nilai rata-rata pretest adalah 56, 16 dan nilai rata-rata post-test adalah 81,26 . Hasil pretest menunjukkan terdapat $63 \%$ peserta didik tidak mencapai ketuntasan dalam belajar. Dan nilai post-test peserta didik yang tidak mencapai ketuntasan ada $16 \%$.

\section{Kelebihan dan Kekurangan Pembelajaran dengan Keta dan Frase dalam Bahan Ajar}

Guru bahasa Arab yang melakukan ujicoba terhadap peningkatan pembelajaran bahasa Arab di madrasah non pesantren melalui indeks kata dan frase dalam bahan ajar menyebutkan kelebihan dan kekurangan pembelajaran dengan Kata dan Frase dalam bahan ajar adalah sebagai berikut:

Pertama, Kelebihan pembelajaran bahasa Arab dengan menggunakan indeks kata dan frase dalam bahan ajar bahasa Arab di Madrasah Ibtidaiyah. Adapun kelebihan tersebut yaitu sebagai berikut:

1) Lebih meningkatkan pemahaman peserta didik karena mereka mudah mencari makna kata dan juga frase yang sulit;

2) Peserta didik aktif Belajar, dengan waktu yang sedikit mereka dapat menguasai materi secara mendalam;

3) Proses belajar mengajar berlangsung dengan baik, seluruh peserta didik aktif melakukan kegiatan belajar;

4) Motivasi belajar peserta didik nampak lebih tinggi; antusiasme peserta didik dalam membaca keras dengan suara lantang saling bersautan antar satu kelompok merupakan salah satu indicator motivasi Belajar mereka lebih tinggi.

5) Sebagian besar peserta didik hasil belajanya meningkat.

Kedua, Adapun kekurangan dari pembelajaran bahasa Arab dengan menggunakan indeks kata dan frase dalam bahan ajar bahasa Arab di Madrasah Ibtidaiyah adalah sebagai berikut: 
1) Adanya peserta didik yang enggan mencari makna mufradat karena tulisan dan tata letak belum sempurna;

2) Bagi peserta didik tingkat Ibtida'yah kamus kurang menarik karena tidak dilengkapi dengan gambar;

3) Masih adanya peserta didik berkemampuan tinggi enggan memberikan penjelasan kepada peserta didik lainnya, karena adanya persaingan dalam nilai hasil belajar;

4) Kamus kurang menarik karena tidak warna dan memerlukan layout yang fullcolor.

Kekurangan di atas sebagai masukan penyusunan kamus tematik bahasa Arab Madrasah Ibtidaiyah, Madrasah Tsanawiyah dan Madrasah Aliyah.

\section{Simpulan}

Pembelajaran bahasa Arab melalui indek kata dan frase di tingkat Madrasah Ibtidaiyah merupakan sebuah terobosan baru dalam strategi pembelajaran. Inovasi dan kreativitas mutlak diperlukan dalam mendesain pembelajaran yang menarik, aktif dan menyenangkan, terutama di tingkat pendidikan dasar yang identik dengan dunia bermain. Mereka bermain sambil belajar atau belajar sambil bermain. Pembelajaran bahasa Arab melalui indek kata dan frase ini diorientasikan agar peseta didik terstimuli belajar bahasa Arab dan mengalami peningkatan dalam aktivitas dan hasil belajar peserta didik. Setelah diujicobakan pada para peserta didik MIN Malang, ternyata hasilnya menujukkan bahwa kelas yang ditreatmen dengan pembelajaran bahasa Arab melalui indek kata dan frase mengalami peningkatan yang signifikan bila dibandingkan dengan kelas kontrol dengan menggunakan metode ceramah. Meskipun demikian kajian pengembangan (research and development) ini masih membutuhkan banyak koreksi dan penyempurnaan dari segala aspek dan tahapannya mulai dari desain produk, uji coba produk hingga produksi massal demi terwujudnya pembelajaran bahasa Arab aktif-menyenangkan (joyfull learning) dan penuh progresivitas. []

\section{Daftar Rujukan}

Albantani, Azkia Muharom. 2015. "Implementasi Kurikulum 2013 pada Pembelajaran Bahasa Arab di Madrasah Ibtidaiyah", Jurnal Arabiyat, Vol. 2 (2).

Alwi, Hasan dkk., 2010. Tata Bahasa Baku Bahasa Indonesia, Jakarta: Pusat Bahasa dan Balai Pustaka.

AR, Syamsuddin, \& Vismaia S. Damaianti, 2009. Metode Penelitian Pendidikan Bahasa, Bandung: Sekolah Pascasarjana UPI \& Remaja Rosdakarya.

Arikunto, Suharsimi, 1993. Prosedur Penelitian Suatu Pendekatan Praktek, Bandung: Rineka Cipta.

Baroroh, R. Umi, 2011. "Kata dalam Bahan Ajar Bahasa Arab Madrasah Ibtidaiyah (Berdasarkan Standar Kompetensi Lulusan dan Standar Isi Madrasah Ibtidaiyah tahun 2008)" dalam Sukiman, dkk (editor), Dinamika Praksis Pendidikan Islam, Yogyakarta: Fakultas Tarbiyah dan Keguruan UIN Sunan Kalijaga.

Galāyain, Muștafa. 1987. Jāmi’ al-Durūs al- 'Arabiyyah, Beirut: al Maktabah al Aşriyyah.

Al-Hasyimi, Ahmad, 2009. Al-Qawād al-Asāsiyah li al-Lughah al-'Arabiyyah, Beirut: Dār al Kutub al-'Ilmiyah.

Majid, Abdul, 2009. Perencanaan Pembelajaran Mengembangkan Standar Kompetensi Guru, Bandung: Remaja Rosdakarya.

Sugiyono, 2009. Metode Penelitian Kuantitatif Kualitatif dan $R \& D$, Bandung: Alfabeta.

Sugono, Dendy. dkk., 2008. Kamus Besar Bahasa Indonesia Pusat Bahasa, edisi keempat, Jakarta: Gramedia Pustaka Utama. 